\title{
野菜中のクロロフェノール類の残留分析
}

(昭和 52 年 12 月 8 日受理)

\author{
飯田勝彦*1渡辺重信* 池田陽男*
}

\section{Analysis for Residue of Chlorophenols in Vegetables}

\author{
Katsuhiko IIDA, Shigenobu WATANABE \\ and Haruo IKEDA
}

(Kanagawa Prefectural Public Health Laboratories; 52-2, Nakao-cho, Asahi-ku, Yokohama)

The purpose of this investigation was to determine chlorophenols residue in vegetables. 2, 4-Dichlorophenol, 2, 4, 5-trichlorophenol, 2, 4, 6-trichlorophenol and 2, 3, 4, 6-tetrachlorophenol were extracted with benzene by a improved essential oil distillator. Chlorophenols in benzene were extracted with $2 \%$ sodium chloride in $0.1 M$ potassium carbonate solution. And chlorophenols were acetylated with acetic anhydride and extracted with $n$-hexane. $n$ Hexane solution was analyzed by gas chromatography using an electron capture detector.

The lower limits of detection in vegetable $(50 \mathrm{~g})$ of 2,4-dichlorophenol, 2, 4, 5-trichlorophenol, 2, 4,6-trichlorophenol and 2,3,4,6-tetrachlorophenol were $0.004,0.002,0.002$ and $0.001 \mathrm{ppm}$, respectively. The recovery of these chlorophenols ranged from 80 to $101 \%$ on addition of $0.5 \sim 10 \mu \mathrm{g}$ of chlorophenols on tomato.

Residue levels of chlorophenols in nine vegetables were analyzed. Chlorophenols were not detected in all samples.

(Received December 8, 1977)

BHC，DDT，ドリン剂などの有機塩素系農薬は，残 留性が高く，食品污染の影響が大きいため使用禁止にな っている. 現在, 使用されている農薬は分解しやすく, かつ安全使用基準があるために食品衛生法に基づく規格 基準の 残留農薬調査ではほとんど検出されない.しか し，易分解性農薬の分解物がそのままの形で，あるいは 活性の強い物質に変化して残留する可能性もあるので, 食品中の農薬分解物について調査する必要がある。従 来, 農薬の分解については多くの総説があるが1),2), 食 品中の分解物の残留分析についてはエチレンビスジチオ カルバメート剂の 分解生成物であるエチレンチオウレ

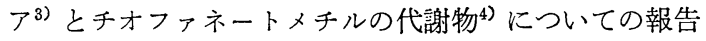
が知られている. しかし, 易分解性農薬の構成成分の一 つであり，ポリクロロジベンゾダイオキシンの前駆物質 になる可能性があるといら報告 ${ }^{5), 8)}$ の知られているク口 ロフェノール類については，その代謝に関する報告》は あるが残留分析についての報告は少ない。すなわち， Farrington $5^{8)}$ は鶏肉中の $2,3,4,6$-テトラクロロフェノ

* 神奈川県衛生研究所: 横浜市旭区中尾町 52-2

*1 現在; 神奈川県公害センター湘南支所: 神奈川県平 塚市豊原町 2-17
一ルおよびペンタクロロフェノールを DNP 化して分析 し，また，Renberg ${ }^{\theta)}$ は2, 4,6-トリクロロフェノール， $2,3,4,6$-テトラクロロフェノールおよびペンタクロロフ ェノールについてイオン交換で精製の後，メチル化によ り水中および魚中の分析をした. しかし，これらはいず れも防ばい剤として使用された場合の残留分析について の報告であり，農薬分解生成物としてのクロロフェノー 儿類の残留分析についての報告は例がない. そこで, 我 々は野菜中のクロロフェノール類の存在を調査する目的 で2,4-ジクロロフェノール，2,4,5-トリクロロフェノー ル，2,4,6-トリクロロフェノールおよび $2,3,4,6$-テトラ クロロフェノールの 4 種のクロロフェノールについて簡 易な分離分析法を検討し，野菜中の残留分析を行ったの で報告する。

\section{実験方法}

1. 試薬

1) クロロフェノール標準溶液

2,4-ジクロロフェノールは東京化成工羓 (株)製特級, 2,4,5-トリクロロフェノールは東京化成工業(株)製 1 級 を石油エーテルで再結晶したもの，2,4,6-トリクロロフ ェノールは東京化成工業(株)製 1 級をリグロインで再結 
晶したもの，2，3，4，6-テトラクロロフェノールは東京化 成工業(株)製化学用をリグロインで再結晶したものをそ れぞれ使用した。 ベンゼン $1 \mathrm{ml}$ 中には，2,4-ジクロロフ ェノール $1 \mu \mathrm{g}, 2,4,5-ト リ ク ロ ロ フ ェ ノ ー ル 0.5 \mu \mathrm{g}, 2$, 4, 6-トリクロロフェノール $0.5 \mu \mathrm{g}, 2,3,4,6$-テトラクロ ロフェノール $0.25 \mu \mathrm{g}$ を含有する溶液とした。

2) 内部標準溶液

$\alpha$-BHC は和光純薬 (株) 製残留農薬分析用標準品を使 用した。 ベンゼン $1 \mathrm{ml}$ 中には $\alpha$ - BHC $0.2 \mu \mathrm{g}$ 含有する 溶液とした。

3） n-ヘキサン，ベンゼンおよび無水硫酸ナトリウム は和光純薬 (株) 製残留農薬分析用試薬を用いた。なお無 水硫酸ナトリウムは $700^{\circ}$ で 6 時間加熱して用いた。

4) 無水酢酸は和光純薬 (株) 製特級試薬を 2 回蒸留し 139〜140の留分を集めた。

5）その他の試薬はすべて試薬特級を用いた．水およ び $2 \%$ 塩化ナトリウム $0.1 M$ 炭酸カリウム溶液は使用 前ベンゼンで洗浄した.

\section{2. 装置}

1）ガスクロマトグラフ

(株) 島津製作所製 GC-3BE (ECD, $\left.{ }^{3} \mathrm{H}\right)$

2) 改良型精油定量装置

スギヤマゲン(株)製，Fig. 1 に示す.

\section{3. 操 作}

\section{1 クロロフェノールの抽出}

野菜 $50 \mathrm{~g}$ を残留農薬試験と同様にミキサーで粉砕均 一化し，1L 丸底フラスコに入れ，水 $500 \mathrm{ml}$ を加え， これにリン酸を $1 \sim 2 \mathrm{ml}$ 加え酸性とし，シリコン樹脂を 塗布した沸石を入れた。これを改良型精油定量装置に装 着した後抽出部には，5〜10 ml の水を入れ，抽出溶媒 としてベンゼン $5 \mathrm{ml}$ を加えた後, マントルヒーターで 2 㭙間加熱還流した．次にベンゼン尿をとり，2\%塩化 ナトリウム $0.1 M$ 炭酸カリウム溶液 $20 \mathrm{ml}$ で 3 回抽出 し水層を合わせアセチル化用試験溶液とした。

\section{2 クロロフェノールのアセチル化}

3.1 で得られた試験溶液に無水酢酸 $1 \mathrm{ml}, n$-ヘキサン $5 \mathrm{ml}$ を加え 1 分間激しく振とらし，アセチル化すると 同時にへキサン層へアセテートを転溶させた， $n$-ヘキサ ン層を水で洗浄し，無水硫酸ナトリウムで脱水した。 そ の後内部標準溶液 $1 \mathrm{ml}$ を加え $5 \mathrm{ml}$ としガスクロマト グラフにより定量した。

\section{4. 検量線の作成}

クロロフェノール標準溶液の0.25，0.50，0.75，1.00 および $1.25 \mathrm{ml}$ をそれぞれベンゼンで $5 \mathrm{ml}$ とし，アル カリ抽出以後の操作は操作の項で述べたように行った. 得られたガスクロマトグラムから $\alpha-\mathrm{BHC}$ とのピーク高 比により検量線を作成した。

\section{5. ガスクロマトグラフィーの条件}

カラム管; 内径 $3 \mathrm{~mm}$ ，長さ $2.1 \mathrm{~m}$ のガラス製

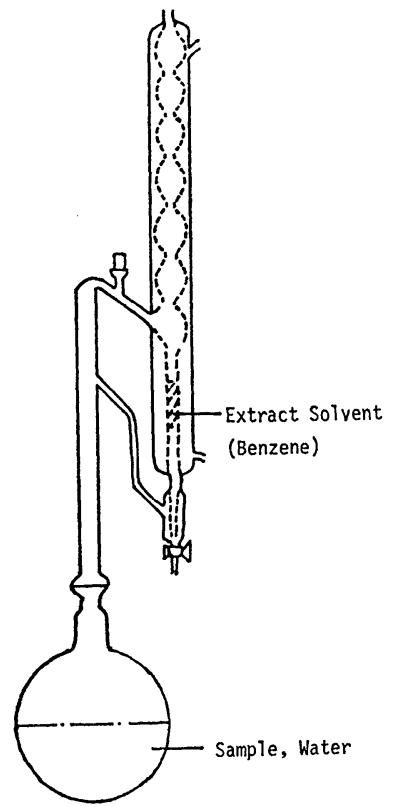

Fig. 1. Distillator

充てん剂； $5 \%$ \%コン OV-17（クロモソルブ W， 80 100メッシュ)

温度; 注入口 $190^{\circ}$, カラム恒温槽 $175^{\circ}$

キャリャーガス; 窒素 $1.0 \mathrm{~kg} / \mathrm{cm}^{2}$

\section{実験結果および考察}

\section{1. 抽出条件の検討}

クロロフェノールの抽出については従来から PCP に ついて多くの方法が報告されていて，ほとんどが，有機 溶媒による抽出であるが，水蒸気蒸留による方法も知ら れている ${ }^{10)}$. また, 改良型精油定量器により農薬を抽出 する方法 ${ }^{11)}$ が報告されている，そこでクロロフェノール の抽出についてはできるだけ使用溶媒量を少なくするた めに Fig. 1 に示す改良型精油定量装置を用い，抽出溶 媒, 抽出時間について検討した.

\section{1 抽出溶媒}

抽出溶媒を検討するためにクロロフェノール標準溶液 $1 \mathrm{ml}$ を水 $500 \mathrm{ml}$ に添加し, 抽出溶媒として $n$-ヘキサ ソ，ベンゼン，酢酸ェチルおよびェチルェーテルを用い 実験操作に従って各クロロフェノールの回収率を比較し た. Table 1 に示したように 4 種のクロロフェノールの 平均回収率で比較すると $n$-ヘキサン $56.5 \%$, ベンゼン $81.8 \%$ ，酢酸エチル $63.5 \%$ ，エチルエーテル $58.8 \%$ でべ ソゼンが最も回収率が良いため，以後抽出溶媒としてべ ンゼンを使用した。

\section{2 抽出時間}

抽出時間を検討するためにクロロフェノール標準溶液 $1 \mathrm{ml}$ を水 $500 \mathrm{ml}$ に添加し, 実験操作に従って蒸留時 
Table 1. Effect of Extract Solvent on the Recovery from Water

\begin{tabular}{l|c|cccc}
\multirow{2}{*}{ Chlorophenols } & \multirow{2}{*}{\begin{tabular}{c} 
Added \\
\cline { 3 - 5 }
\end{tabular}} & \multirow{2}{*}{$(\mu \mathrm{g})$} & \multicolumn{4}{|c}{ Recovery (\%) } \\
\cline { 3 - 5 } & & $n$-Hexane & Benzene & Ethyl ether & Ethyl acetate \\
\cline { 3 - 5 } & 1.00 & 68 & 95 & 84 & 62 \\
2, 4-Dichlorophenol & 0.50 & 59 & 84 & 76 & 77 \\
2, 4, 5-Trichlorophenol & 0.50 & 45 & 77 & 52 & 52 \\
2, 4, 6-Trichlorophenol & 0.25 & & 71 & 42 & 44
\end{tabular}

Table 2. Effect of Distillation Time on the Recovery from Water

\begin{tabular}{|c|c|c|c|c|c|c|c|}
\hline \multirow{3}{*}{ Chlorophenol } & \multirow{3}{*}{$\begin{array}{l}\text { Added } \\
(\mu \mathrm{g})\end{array}$} & \multicolumn{6}{|c|}{ Recovery (\%) } \\
\hline & & \multicolumn{6}{|c|}{ Distillation time $(\mathrm{hr})$} \\
\hline & & 0.5 & 1.0 & 1.5 & 2.0 & 2.5 & 3.0 \\
\hline 2, 4-Dichlorophenol & 1.00 & 66 & 73 & 84 & 95 & 80 & 84 \\
\hline 2, 4, 5-Trichlorophenol & 0.50 & 55 & 65 & 80 & 74 & 81 & 81 \\
\hline 2, 4, 6-Trichlorophenol & 0.50 & 62 & 66 & 77 & 73 & 74 & 76 \\
\hline 2, 3, 4, 6-Tetrachlorophenol & 0.25 & 39 & 51 & 63 & 68 & 69 & 71 \\
\hline
\end{tabular}

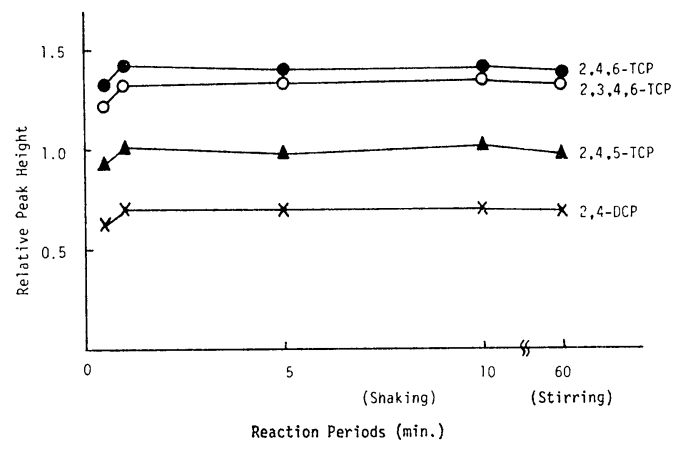

Fig. 2. Effect of reaction periods for acetylation of chlorophenols

間を $0.5,1.0,1.5 ， 2.0 ， 2.5$ および3.0時間と変化させ てクロロフェノールの回収率を比較した. 結果は Table 2 に示してあるが 4 種のクロロフェノールの平均值を比 較すると，0.5時間で $55.5 \% ， 1.0$ 時間で $63.8 \% ， 1.5$ 時 間で76.0\%と增加した。. 以後， 2 時間で $77.5 \%, 2.5$ 時 間で76.0\%，3 時間で78.0\%とほぼ77\%前後で一定とな り,これ以上回収率の向上は望めないので抽出時間は 2 時間とした.

\section{3 アルカリによる抽出}

改良型精油定量装置により抽出したベンゼン溶液から 農薬などの他の妨害物を除去し，クロロフェノール類を アセチル化しやすくするためにアルカリ溶液で抽出し た. Chau ら ${ }^{12)}$ が PCP について行った方法に従い 0.1

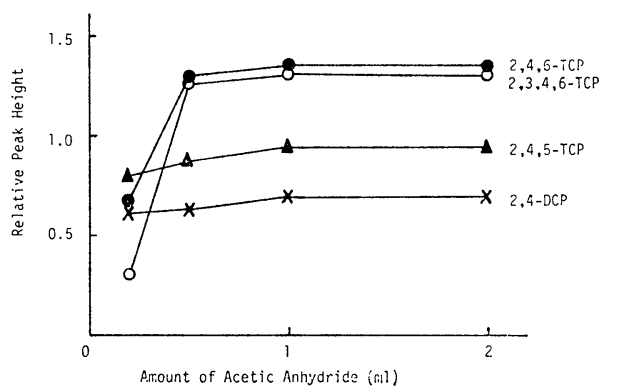

Fig. 3. Effect of amount of acetic anhydride for the acetylation of chlorophenols

$M$ 炭酸カリウム溶液で抽出すると野菜の場合ではエマ ルジョンを形成したので， $2 \%$ 塩化ナトリウム $0.1 M$ 炭酸カリウム溶液をベンゼンからの抽出液とした。この 場合, 抽出率, アセチル化の反応性とも変化しなかっ た.

\section{2.アセチル化の検討}

從来，アセチル化についてはピリジンなどの触媒を使 ってアセチル化する報告が多い. しかし，触媒による妨 害物の混入も考えられ，また GCに注入する前に触媒を 除く手間もかかる．そこで Chau ら ${ }^{12)}$ の抽出したアルカ リ溶液に $n$-ヘキサンおよび無水酢酸を入れてアセチル 化させ，同時にアセテートを $n$-ヘキサン層へ転溶させ る方法が抽出操作も必要ないのでこの方法を用いた. 次 に反応時間，無水酢酸量について検討した。 
Table 3. Reproducibility of Acetylation of Chlorophenols

$n=5$

\begin{tabular}{|c|c|c|c|c|c|}
\hline \multirow{2}{*}{$\begin{array}{c}\text { Volume } \\
(\mathrm{ml})\end{array}$} & \multirow{2}{*}{ Statistics } & \multicolumn{4}{|c|}{ Chlorophenols } \\
\hline & & $\begin{array}{l}\text { 2, 4-DCP } \\
\text { (1 ppm) }\end{array}$ & $\begin{array}{c}2,4,5-\mathrm{TCP} \\
(0.5 \mathrm{ppm})\end{array}$ & $\begin{array}{l}2,4,6-\mathrm{TCP} \\
(0.5 \mathrm{ppm})\end{array}$ & $\begin{array}{c}2,3,4,6-\mathrm{TCP} \\
(0.25 \mathrm{ppm})\end{array}$ \\
\hline \multirow[t]{3}{*}{0.25} & $\bar{x}$ & 0.21 & 0.33 & 0.47 & 0.44 \\
\hline & $\sigma$ & 0.013 & 0.015 & 0.005 & 0.022 \\
\hline & $C(\%)$ & 6.25 & 4.55 & 0.96 & 5.09 \\
\hline \multirow[t]{3}{*}{0.50} & $\bar{x}$ & 0.38 & 0.55 & 0.79 & 0.71 \\
\hline & $\sigma$ & 0.021 & 0.021 & 0.016 & 0.016 \\
\hline & $C(\%)$ & 5.42 & 3.85 & 2.08 & 2.32 \\
\hline \multirow[t]{3}{*}{0.75} & $\bar{x}$ & 0.55 & 0.79 & 1.13 & 1.03 \\
\hline & $\sigma$ & 0.019 & 0.015 & 0.023 & 0.029 \\
\hline & $C(\%)$ & 3.48 & 1.92 & 2.02 & 2.77 \\
\hline \multirow[t]{3}{*}{1.00} & $\bar{x}$ & 0.71 & 0.95 & 1.38 & 1.33 \\
\hline & $\sigma$ & 0.022 & 0.023 & 0.030 & 0.032 \\
\hline & $C(\%)$ & 3.05 & 2.41 & 2.19 & 2.37 \\
\hline \multirow[t]{3}{*}{1.25} & $\bar{x}$ & 0.84 & 1.16 & 1.63 & 1.61 \\
\hline & $\sigma$ & 0.030 & 0.042 & 0.057 & 0.032 \\
\hline & $C(\%)$ & 3.52 & 3.62 & 3.51 & 1.93 \\
\hline
\end{tabular}

\section{1 反応時間}

反応時問について恰討するためにクロロフェノール標 準溶液 $1 \mathrm{ml}$ をベンゼンで $5 \mathrm{ml}$ とし，アルカリで抽出 後, $n$-ヘキサン $5 \mathrm{ml}$, 無水酶酸 $1 \mathrm{ml}$ を加えた。 反応時 間を，0.5，1，5および 10 分間振とうした場合と 1 時 間かく拌した二つの場合についてそれぞれの GC の $\alpha$ BHC に対するピーク高比でアセテート生成率を比較し た. Fig. 2 に示すとおり 0.5 分間振とうでは平均 1.03 で, 1 10分間振とうおよび 1 時間かく拌とも平均 1.08 1.12でほとんど差がなかったＰPC については，Chau ら ${ }^{12)}$ は 1 時間かく找，岡ら ${ }^{133}$ は10分間振とうでアセチル 化しているが，4種のクロロフェノールでは区応時間 1 分間でほぼ最高值に達しそれ以後反応はないため反応時 間は 1 分間振とうすることにした。

\section{2 無水酢酸量}

無水酢酸量を調べるために，クロロフェノール標準溶 液 $1 \mathrm{ml}$ をベンゼンで $5 \mathrm{ml}$ とした後, アルカリで抽出 乙, 实験操作のうち無水酶酸量を $0.2,0.5,1.0$ おうよび $2.0 \mathrm{ml}$ と変えてアセテートの生成率を調べた. その結 果, Fig. 3 に示すと拈り無水酢酸の量は $1 \mathrm{ml}$ で最高值 を示すため, 無水酢酸の量は $1 \mathrm{ml}$ とした.

\section{3 再 現 性}

検量線の項の操作をそれぞれ 5 回繰り返し行い，それ ぞれのクロロフェノールのアセチル化の反応の再現性を 求めた. Table 3 に示すように, 2,4-ジクロロフェノー ル $1 \mathrm{ppm} 0.25 \mathrm{ml}$ 添加の場合变動係数 $6.25 \%$ と少し高い がほぼさ4\%以下の誤差であり良好な再現性を示した。

\section{3. 検 量 線}

实験操作の検量線の作成の項により検量線を作成し Fig. 4 に示した。横軸にクロロフェノール重量を示し， 縱軸に相対ピーク高さ (クロロフェノールのアセテート のピーク高さを $\alpha$-BHC のピーク高さで除したもの) を 示した. 2,4-ジクロロフェノールは $0.2 \sim 1.2 \mathrm{ng}, 2,4$, 5-トリクロロフェノールと2,4,6-トリクロロフェノール は $0.1 \sim 0.6 \mathrm{ng}, 2,3,4,6$-テトラクロロフェノールは $0.05 \sim 0.3 \mathrm{ng}$ の範囲でほぼ直線性が得られた.

\section{4. 添加回収実験}

ダイコンおよびトマトのホモジネートにクロロフェノ 一儿標準溶液 $1 \mathrm{ml}$ および10倍濃度の溶液 $1 \mathrm{ml}$ を添加 して回収率を求めた. 結果は Table 4 に示した. ダイ コンでは $2,4,5$-トリクロロフェノール $5 \mu \mathrm{g}$ 添加の場合 $82 \%, 2,3,4,6$-テトラクロロフェノール $0.25 \mu \mathrm{g}$ 添加の 場合79\%,2.5 $\mu \mathrm{g}$ 添加の場合76\%,トマトでは2,3,4,6-テ トラクロロフェノール $0.25 \mu \mathrm{g}$ 添加の場合 $80 \%$ と若干低 いが他はすべて $85 \%$ 以上であった．特にトマトでは平均 93.6\% と良好な回収率を得た。4種のクロロフェノール の中では2, 3, 4, 6-テトラクロロフェノールが76 85\%と 低かった。 また，Fig. 5 にダイコンおよびダイコンにク ロロフェノール標準溶液 $1 \mathrm{ml}$ 添加したとさのガスクロ マトグラムを示してある. 若干妨害ピークが見えるがい ずれも標準のクロロフェノールのアセテートのピークと 一致しないので測定上差し支えないと思われた。したが って，さらにカラムクロマトグラフィーによるクリーン アップは行わなかった。 また，本実験操作による検出限 界は2, 4-ジクロロフェノール0.004 ppm, 2, 4, 5-トリクロ 


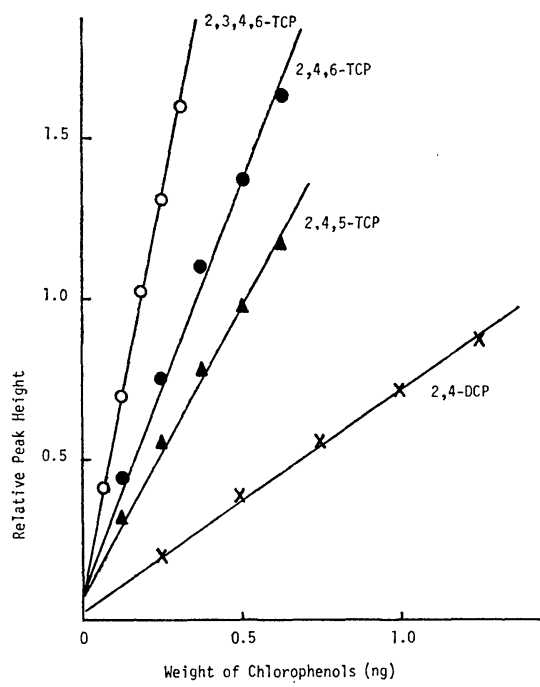

Fig. 4. Calibration curve of chlorophenols

Table 4. Recovery of Chlorophenols Added to Vegetables

\begin{tabular}{l|c|cc}
\multirow{2}{*}{ Chlorophenols } & Added & \multicolumn{2}{|c}{ Recovery $(\%)$} \\
\cline { 3 - 4 } & $(\mu \mathrm{g})$ & Radish & Tomato \\
\hline 2, 4- & 1.0 & 86 & 97 \\
Dichlorophenol & 10.0 & 96 & 99 \\
2, 4, 5- & 0.50 & 98 & 99 \\
Trichlorophenol & 5.0 & 82 & 88 \\
2, 4, 6- & 0.50 & 98 & 100 \\
Trichlorophenol & 5.0 & 85 & 101 \\
2, 3, 4, 6- & 0.25 & 79 & 80 \\
Tetrachlorophenol & 2.5 & 76 & 85
\end{tabular}

ロフェノールおよび2, 4, 6-トリクロロフェノール 0.002 $\mathrm{ppm}, 2,3,4,6$-テトラクロロフェノール $0.001 \mathrm{ppm}$ で あった。

5. 野菜の測定結果

この分析法を用いて神奈川県下の市場から収去した 9

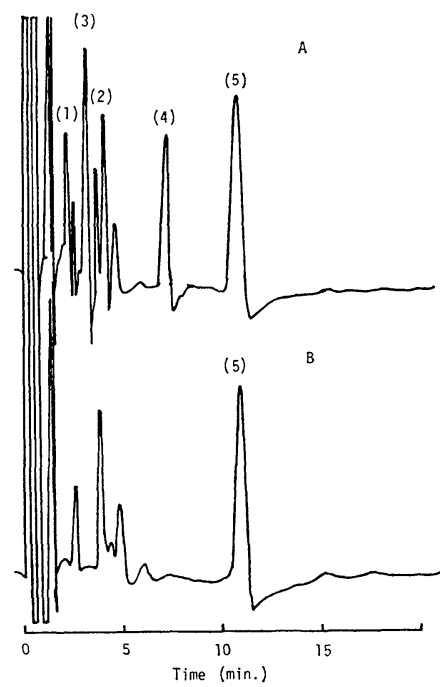

Fig. 5. Gas chromatograms of extracts from radish after acetylation

A, Extract to which $1 \mu \mathrm{g}$ of 2,4 dichlorophenol (1), $0.5 \mu \mathrm{g}$ of $2,4,5$-trichlorophenol; (2), $0.5 \mu \mathrm{g}$ of $2,4,6$-trichlorophenol; (3), $0.25 \mu \mathrm{g}$ of $2,3,4,6$ tetrachlorophenol; (4), and $0.04 \mu \mathrm{g}$ of $\alpha$-BHC; (5), added before acetylation.

B, Extract after acetylation.<smiles>O=C(O)COc1ccc(Cl)cc1Cl</smiles>

$2.4-D$<smiles>CCOP(=S)(OCC)Oc1ccc(Cl)cc1Cl</smiles><smiles>CCOP(=S)(Oc1ccc(Cl)cc1Cl)c1ccccc1</smiles>

EPBP<smiles>COc1cc(Oc2ccc(Cl)cc2Cl)ccc1[N+](=O)[O-]</smiles>

Chlomethoxynil<smiles>Oc1c(Cl)c(Cl)c(Cl)c(Cl)c1Cl</smiles>

P C P<smiles>COP(=S)(OC)Oc1cc(Cl)c(Cl)cc1Cl</smiles>

Ronnel<smiles>O=[N+]([O-])c1ccc(Oc2c(Cl)cc(Cl)cc2Cl)cc1</smiles>

CNP

Fig. 6. Pesticides producing chlorophenols 
種類の野菜についてクロロフェノールの残留調查を行っ た. 分解してクロロフェノールを生成する可能性のある 農薬を Fig. 6 に示した。 それぞれの農薬からその構成 成分のクロロフェノールが生成し，PCP からは2, 3, 4,6テトラクロロフェノールなど 3 種のテトラクロロフェノ ールと 5 種のトリクロロフェノールが生成する2). この なかで現在使用されているのは，殺虫剤として ECP お よび EPBP, 除草剂として 2,4-D, NIP, CNP およびク ロメトキシニル，除草剤および殺菌剤として PCP, 植物 生長調整剂として $2,4,5-\mathrm{T}$ であり，ロンネルは登録され ていない。また，調査した野菜についてみると，ニンジ ンおよびダイコンには EPBP, NIP および CNPを， キャベッおよびスイカには EPBP および NIP を，キ ュウリには EPBP および ECPを，ナツミカンには PCP および 2, 4,5-Tを使用している. したがって，2,4-ジク ロロフェノールはニンジン, ダイコン, キャベッ，スイ カおよびキュウリに，2,4,5-トリクロロフェノールはナ ツミカンに，2,4,6-トリクロロフェノールはニンジンお よびダイュンに， $2,3,4,6$-テトラクロロフェノールはナ ツミカンに残留する可能性があり，その他のトマト，ナ スおよび生茶はクロロフェノールが残留する可能性のな いものであった．結果としては実際にクロロフェノール を分解生成する㖘薬が使用されている野菜についても， 使用されていない野菜と同様に 4 種のクロロフェノール は前項検出限界の範囲ではすべて検出されなかった。

\section{まとめ}

農薬の一次分解産物であるクロロフェノール類につい て野菜中の存在を調查する目的で改良型精油定量装置を 用いて抽出し，アセチル化する簡便な分析法を検討し， この方法で分析した。そ結果，野菜中には 4 種のク口
ロフェノールは検出されなかった，したがって，クロロ フェノール類は野菜中には残留せず，さらに分解あるい は重合していると考えられる．クロロフェノール類の変 化生成物について他の農薬との関連も考えられるのでさ らに調査する必要があると思われる。

\section{文献}

1) 上杉康彦, 㙇野豊, 松中昭一, 見里朝正, 宫本 純之：化学総説，2，57 (1973).

2) 鍬塚昭三: 農薬科学, 3, 107 (1976).

3) 宇野正清, 上田栄次, 岡田 作, 除地義樹: 食衛 誌. 18, 53 (1977).

4) 伊藤誉志男，豊田正武，慶田雅洋：同上， 18，26 (1977).

5) Plimmer, J. R., Klingebiel, U. I.: Science, 174, 407 (1971).

6) Higginbotham, G.R., Huang, A., Firestone, D., Verrett, J., Ress. J., Campbell. A. D.: Nature, 220, 702 (1968).

7) Shafik, T.M., Sullivan, H.C., Enos, H.R.: J. Agr. Food Chem., 21, 295 (1973).

8) Farrington, D.S., Munday, J.W.: Analyst, 101, 639 (1976).

9) Renberg, L.: Anal. Chem., 46, 459 (1974).

10）能勢和夫：農薬生産技術. 14，36 (1966).

11) 松本 浩, 岡 尚男, 河村典久, 栖府淔大：食衛 誌. 16, 165 (1975).

12) Chau, A.S. Y., Coburn, J. A.: J. Assoc. Offic. Anal. Chem., 57, 389 (1974).

13) 岡 日出生, 永井夏, 田坂美和子: 食衛誌. 18, 419 (1977). 